\title{
One good book away from becoming a reader: First Nations literature in a northern classroom
}

\author{
Susan Catlin \\ Queen's University
}

I arrived in the isolated, northern community of Big River, Northwest Territories on August 17, 1987. In a pottery class that I had taken that summer in preparation for teaching Art, just one of many courses I was to teach in addition to English Language Arts, an astrologist in the class told me that August 17 was a very auspicious day to begin something new. I cannot recall what was happening in the cosmos, but I was glad to hear that the stars were with me on this career move. On my first teaching day ever, a little more than a year before my arrival in Big River, a tornado swept by the school in central Ontario where I was to work as a substitute teacher. The skies clouded over that May morning and a great hush descended as I disembarked from my car. By 2 o'clock, my students and I were huddled against the cement wall of our classroom watching through rain sheeted windows as tree branches snapped, and were hurled through neighboring sheds, and power lines came spiraling down past uprooted playground equipment. Perhaps it is best that I was not into astrology or I might have given up teaching then and there, but in spite of the welcome words of my pottery classmate, my arrival in Big River felt as inauspicious as my first day of teaching in Ontario.

I arrived disheveled from two days of travel and nauseous from the long ride and diesel fumes of the DC 3, the ancient armored airplane that transported me from Yellowknife. The woman from personnel, who assured me via previous telephone conversations that she would pick me up at the airport, was nowhere in sight. After a long 
wait, I gave up hope and caught a ride with helicopter pilots into town. Seated between the two, in the cab of a pickup, the older driver teased me about my potential to make the younger pilot's boring Big River nights more interesting before dumping me at the school with all of my bags. The woman, who was supposed to have picked me up at the airport, was also supposed to have arranged my living accommodations. I sat on the steps of the school and waited for someone to show up.

Big River did not look like it was supposed to: like the pristine, untouched wilderness of the tourist brochures I'd read down south. From the air, the environs had looked all brown and green and pot holey, and on the ground the land looked like a place where trees held on for dear life. The town is situated on an island that had been razed to make room for the government's aluminum sided buildings and the people's small wooden houses. The day was hotter than I expected, and the town was terribly dusty. My feet were crisscrossed with the dirty pattern made by my fashionable yellow sandal straps, and a plague of locusts hopped against my bare legs. I hadn’t expected grasshoppers, yet there were hundreds of them; I've never seen them that bad in town since that summer. Finally, the school secretary arrived and gave me a quick tour through the dark green school. The floors were sloped and bumpy and the carpets smelled like old socks. (Fortunately, the school was renovated a few years later.) The previous teacher had left all of his castaway junk in my classroom, but as I had arrived two weeks early, I had time to sort it out. The secretary gave me my class lists, and I decided to get a room at the hotel until someone came back from vacation to help me find a place to live.

I cried as I studied those lists. With only one year of teaching experience as an itinerant French teacher in a rural Ontario town, I was expected to teach 13 levels in five 
different courses. There were students in my grade 9 and 10 classes who were nearly as old as I was. I thought about how different the place seemed from what I knew and from what I had imagined, and I wondered what I would have to offer the young people of this community.

Big River has a European and a Dene name, and is a community of about 1,100 people, the majority of whom are of Dene descent. Big River (not the town's real name) was originally established as a trading post because of its advantageous position at the juncture of two rivers. Big River's two claims to fame have been the Pope's visit, and before that, the Mackenzie Valley Pipeline Inquiry. From 1974-1977, hearings were conducted in every settlement in the western Northwest Territories. At that time, many Native people were concerned about the ways the proposed pipeline might affect their traditional lifestyles. Many non-Native people supported the development of the pipeline for the sake of economic development in the North. When Justice Thomas R. Berger came to Big River, the community was so divided that two hearings were held. After all of the hearings in the North, the pipeline was postponed until further study could establish the effects of the pipeline on wildlife and the traditional way of living (Berger, 1999). The Berger Inquiry occurred a decade before I arrived, but the presence of two different ways of looking at potential economic development in the North still lingered.

There are two schools in Big River: one for kindergarten to grade 6, and the other for 7 to 12 . When I arrived in 1987, the high school had just extended its grades to 10 . After grade 10, students could go to the regional high school in Yellowknife, but many did not go as it was too far from home. The Big River high school continued extending its grades until it became a full high school in 1991. There are seven smaller communities in 
the surrounding region, two of which eventually extended their grade offerings to 12 , but during the time I taught at Big River many students came to complete their high school.

I worked in the high school for 11 years. Over the years, I taught a variety of subjects in addition to high school English, but I suspect I taught those subjects grounded in the pedagogy of my subject discipline. About 70 per cent of the students were Dene (from town and from the outlying communities) and the other 30 per cent were NonDene including the children of long time residents and those of a more transient population. For the most part, all of the students got along very well. Our grade 10 to 12 population was around 80 students, and was divided into academic, general, and basic levels. In the Northwest Territories, we create our own curriculum to grade 9, and then follow Alberta for secondary school.

After my first few years in the community, I had very few difficulties with classroom management. Once I felt I had the community's trust, I found the students very cooperative, thoughtful, and respectful. All of them had dreams for their own happiness, and all hoped to contribute to their community. But as fond as I was of my students, I cannot characterize very many as zealous overachievers in the terms set by those in authority at school. Attendance and late arrivals were considered a major problem at our school, as was a general malaise toward study, and homework was rarely completed. I would also characterize many as reluctant or struggling readers. I did recognize that my students were reading texts outside of school, but I defined reader as Bronwyn Williams does as "a person who makes particular kinds of intertextual connections, who asks particular kinds of questions of a text, who talks about more than the text's meaning and analyzes its nature" (Williams, 2004, p.687). 
I struggled to get my students to take on this definition of reader as I felt it would lead to more success in school. Throughout his career, John Ogbu considered the variance in the achievement of minority students in schools through a comparative study of minority education. Minorities, whom Ogbu (1998) classifies as either voluntary or involuntary, are defined by the nature of their power relations to the majority group, not by their numbers. Voluntary minorities according to Ogbu, are people who immigrated to a country in hope of a better life for their family; generally, the children of voluntary minorities have a positive attitude toward schooling and have high success rates. Involuntary minorities are people who have a history of subordination and exploitation and often struggle in school. Within each group, Ogbu recognizes that there are individual exceptions, but his work consisted of looking for dominant patterns in beliefs and behaviors in the larger group.

Involuntary minorities in the United States, such as Black Americans, Hispanic Americans, and Native Americans, desire to succeed in white America but perceive many historical and contemporary obstacles due to their status or race. They respond to these barriers through the patterned strategies of assimilation, accommodation without assimilation, ambivalence, resistance and opposition, or encapsulation. Ogbu's culturalecological theory recognizes that many historical, community, and educational factors contribute to school achievement for these students. "Ecology is the 'setting,' 'environment," or 'world of people'... and 'cultural,' broadly refers to the way people (in this case minorities) see their world and behave in it" (Ogbu \& Simon, 1998, p. 2).

His two part theory considers the way minorities are treated or mistreated in schools, in addition to the way that minorities perceive and respond to this treatment. As 
a non-First Nations teacher in a First Nations context, I focused my attention on my students' responses to schooling in an effort to modify my behavior in the classroom. My primary focus was on what Ogbu (2004) would identify as collective identity which "refers to people's sense of who they are, their "we-feeling or "belonging" (p.3). Ogbu has suggested that involuntary minorities develop oppositional identities that take some of their sense of who they are from their response to their treatment by white society. To some extent then, First Nations' identities are defined by their differences from non-First Nations'. Thus, my students may not have been willing to give up aspects of themselves, just because I required them to. Ogbu acknowledges that minority students do not reject the idea of getting good grades; what they reject are "White" attitudes and behaviors conducive to getting those good grades (Ogbu \& Simons, 1998).

Ogbu's explanation seems a plausible framework to use to explain my students' lack of engagement with school. At the time I was puzzling out how to teach, I intuited that my responsibility was to create a classroom that was open and hospitable and responsive to the needs of my students. I held high standards for the cognitive abilities of my students, and expected their behaviors to meet them. I strived to create a pedagogy with them: one that began with what was familiar. I participated, observed, and listened in the life of the community, and I began to read literature by First Nations people. Initially, I had hoped that the literature would help me better understand my students, but I soon realized that this literature might motivate my students to begin the habit of reading. In my English Language Arts classrooms, I had students read novels on their own, and in small groups of four or five. During any English Language Arts course, I often read aloud, and I always lead one whole class study of a novel. I worked to get to 
know my students, and to identify a starting point for their reading. "Identifying a starting point requires gathering relevant information about students' skills, abilities, and knowledge" (Brozo \& Hargis, 2003. p. 14).

In my third year of teaching, I came upon the novel that first put the notion in my head that students needed only to find one good book before they would willingly explore the identity of reader. We have a great book store in Yellowknife, the largest community and capital of the Northwest Territories, and after a visit to town I returned home with April Raintree by Beatrice Culleton (1984). Many of my students in the late eighties and early nineties were much older than their southern counterparts. It was not uncommon to find 18 year olds in a grade 10 course. The range of life experiences in my classes were varied, as I may have had, for example, 15 year old students who were just beginning to be interested in dating along with older students who were already parents. In the grade 10 class where students first read April Raintree, all but one were of Dene ancestry, and all by virtue of growing up in our community had intimate knowledge of its social problems. I believe it is Culleton's frankness in examining the tragedies and struggles in her characters' lives that touched my students so deeply.

After that book, students always asked for more like it, but I am afraid I had nothing to offer then, that was like Culleton's first novel. My students said that they loved Cheryl, the protagonist's fiery sister, who refuses to deny her Metis heritage. As Cheryl grows older, she wants to be a social worker to help her people and she tries to help herself by talking with elders at the Native Friendship Center. Unfortunately, Cheryl's feisty nature dissipates over time, and she becomes resigned to a difficult and unhappy life. Cheryl, Beatrice Culleton tells us in an interview in Contemporary 
Challenges Conversations with Canadian Native Authors by Hartmut Lutz (1991), lacks the cultural foundation she needs to support her through her search, and so her idealism is easily shattered.

I discovered Contemporary Challenges in 1991, the year it was published, and my students enjoyed the interview in that collection. Culleton explains that writing April Raintree was part of her healing as she, like her characters, was raised in foster care and had two sisters who committed suicide. As a result of that book, my students and I had powerful discussions about the foster care experience of indigenous people, about racism, and about the disillusion of young people who are left to their own devices to forge their identity. The book also sparked conversations about writing and its many functions. Other interviews, by authors whose work they admired such as Tomson Highway, Daniel David Moses, Rudy Slipperjack, and Jordan Wheeler were of interest to my students. I often had senior high school students read the interview by Lenore Keeshig-Tobias as she raises the issue of voice appropriation and we had many lively debates in class afterward.

The success of Contemporary Challenges led me to seek out books of literary analysis of First Nations literature by First Nations scholars. The full texts were often too complex for my students, so we examined excerpts. In 1993, I designed a First Nations literature course for my grade 11 students and integrated the minimum amount of the required readings from the Alberta curriculum into that course. My students researched the history of First Nations writing in Canada, and read various genres of writing by First Nations writers. Students learned that most of the writing about First Nations people was written by Non-First Nations people, and that the original audience for this writing was also Non-First Nations. Only in the 1970's did writing by First Nations people and for 
First Nations people take root, but this literature has been growing ever since.

Unfortunately, the market for First Nations literature has been dictated by the tastes of the original and longstanding Non-First Nations audience, and by the norms established by the writing of predominantly Non-First Nations writers. Ironically, at the time I was searching for books for my students, First Nations authors had difficulty breaking into the niche of the First Nations literature market, and most were published by small independent presses (Young-Ing, 1993). I had to acquire these books from small presses before they were out of print, as chances were they would not be reprinted. The books were expensive as they were published in small runs, but I was fortunate to have the support of our school librarian who worked with me over the years to build a library of First Nations literature and criticism. But despite our inquiry into Canadian First Nations literature, I still could not find other novels that rivaled the overall success of April Raintree.

I continued looking and had some success in the classroom with work by Jeannette Armstrong, Drew Hayden Taylor, Thomas King, and Lee Maracle. By the early nineties I was also reading American writers like Sherman Alexie, Louise Erdrich, Linda Hogan, Leslie Marmon Silko, and James Welch. I had organized my reading by Canadian First Nations and American Indian although as Thomas King (2003) says in The Truth About Stories "the border doesn't mean that much to the majority of Native people in either country. It is after all, a figment of someone else's imagination"(King, 2002, p. 102). In 1996, I came across, The Lesser Blessed, a book had some of the mass appeal of April Raintree, although I didn't ever teach it as a whole class novel. 
The author, Richard Van Camp is a writer of Dene ancestry who was raised in Fort Smith, Northwest Territories. When he was a junior writer for the $\mathrm{CBC}$ television program North of Sixty, he visited our school. North of Sixty ran for six years, and was set in the fictitious settlement of Lynx River in the very real Dehcho region. When the show was in the planning stages, the writers and producers came to town to discuss authenticity for the show's stories with local elders, and another teacher and I convinced them to come to the school to talk with the students. Often the North of Sixty people were on that southern phenomenon called a tight schedule and were unable to visit, but Jordan Wheeler, a senior writer, often made the effort to come to see us. All of the students enjoyed his visits, especially the young men who had read his book of three novellas called Brothers in Arms. (The boys, as I recall, enjoyed the story entitled "Hearse in the Snow" about two estranged brothers who reunite for their father's funeral. The brothers wind up trapped in the hearse with their dead father's body, after the car has gone off the road in a snow storm.) Eventually, other writers did come to visit and toward the end of the run of North of Sixty, Richard Van Camp was one of them. He was 22 at the time, and already a published author of short stories and poems. His writing was of real interest to my students, as he was a northern boy who made good.

The Lesser Blessed is 119 pages long, and the short length of this novel is an incentive for many of my students who would not read long books. Personally, I preferred The Lesser Blessed to April Raintree because Van Camp's characters are, in my opinion, more fully drawn. In Culleton's story, the two sisters represent two parts of the same person as she struggles to find her identity. I loved Larry, the central character in The Lesser Blessed, who struggles to come to terms with the events he has witnessed, the 
things that have been done to him, and the terrible act that he has committed. And I liked his friend Johnny, even though the real life Johnnys aren't as easy to like in the classroom!

I offered this book as a choice for individual reading, or for literature circles. Although, generally speaking, my male students preferred to read books about boys and often stayed unmotivated to read longer than the girls, they had enjoyed April Raintree. I think the girl's point of view in that book made it safer for them to engage with and discuss the book's sensitive issues. The boys who read The Lesser Blessed liked the story, but did not make (or admit to) as many personal connections to the text as they had with April Raintree. I didn't ever experiment with literature circles that would have had the girls reading April Raintree and the boys reading The Lesser Blessed, but in a senior English class of 10 girls and 10 boys, I had the girls study and then present excerpts from Tomson Highways The Rez Sisters, while the boys studied and presented excerpts from his Dry Lips Oughtta Move to Kapuskasing.

Both the plays by Highway and the novel by Van Camp raise the issue of the appropriateness of the subject matter for classroom texts. Unfortunately, young adult literature by First Nations writers, Canadian or American, was hard to find in the late eighties and the early nineties. Highway's characters swear and this is a problem for a play that is read aloud in school. I offered my students the choice to read the text with the swear words present or deleted, and I modeled both approaches in my own reading. Modeling and discussion removed the possibility that students would be titillated by the opportunity to swear in class. Students discussed why swearing is so much a part of the lives of Highway's characters, and while many felt his use of obscenities might be an 
accurate portrayal of life on a reservation, others felt that he was creating a stereotype of First Nations people. The students with whom I worked were old enough to consider the mature issues of the play and to appreciate Highway's humor and artistry.

Van Camp also presents an accurate portrayal of certain sectors of the northern teenage population in his book The Lesser Blessed. These characters not only use objectionable language (although not as frequently as the characters in Highways plays) but they also drink and do drugs. On page 37 , there is a very thorough description of the boys smoking hash using the hot knives method. The boys in this book are also obsessed with having sex and in several instances they get what they are after. But I did not feel that Van Camp glorified or made cool this partying life; instead, he examines the circumstances under which kids get initiated into this life style, and explores its consequences.

Van Camp engages with social issues similar to those in Big Rivers, and creates plausible northern characters in a well crafted book. I think students were surprised to find a familiar reality represented in literature and appreciated that his book ends on a positive note. Even if it did not, I did not try to motivate my students to read, while simultaneously ensuring that they encountered an appropriate world in order to "reposition the self according to norms deemed acceptable" (Greenbaum, 1997, p.19). I wanted my students to develop into independent readers capable of making meaning for themselves.

Another book that examines the search for identity, but in a less traumatic context, is Richard Wagamese's A Quality of Light, published in 1997. This is a beautifully written book devoid of the behaviors deemed inappropriate for literature read 
in schools, but this book has the misfortune to be 327 pages long. No matter how good the book, non-reading students would not attempt a book that was more than 160 pages. I talked about the book and shared passages with my students and I did have one student who was a voracious reader, go on to read the book for herself. Other less experienced readers would have had difficulty understanding how flashback functions in the narrative structure, but for her, this was not a problem.

The protagonist in the book, Joshua Kane, is an Ojibwa (Anishnabe) boy who was adopted into a loving, white, farming family. He lives a very happy life on the farm and is totally accepted in his community as "the Kane boy." He finds a friend in Johnny Gebhart, who moves to town at age eleven, and introduces him to the world of Native people through stories and books. Johnny is fascinated by Native cultures and is rather disheartened by Joshua's lack of "authentic" Nativeness. John's family life is fraught and he finds refuge in his books and dreams of being a traditional Native person.

When the boys leave behind the security of their small, rural elementary school and move to a larger high school in a neighboring town, Joshua has his first encounter with racism. Joshua's parents thought they were protecting him from the mean spiritedness of people, but realize that they have failed their son by not preparing him to face this inevitable, nasty experience. Johnny is his closest ally and is surprised that Joshua does not lose faith in people because of his experience. Joshua keeps the peaceable approach to life that his adoptive parents have given him. "One of these days Kane, you're going to run out of cheeks to turn" (p.39), Johnny tells him, but this never happens to Joshua Kane who becomes pastor of a Christian church, marries, and raises a family. 
The story picks up years later, when Joshua is asked by the RCMP to come to Calgary to help talk down Johnny Gebhart who is holding hostages in the Indian Affairs office. Johnny began a full-scale initiation into Native cultures after high school, learning from various tribal elders and involving himself in militant aboriginal organizations. The novel ends as Joshua and Johnny come face to face with their identities-- their Nativeness and whiteness, but most importantly, their shared humanity.

The characters in A Quality of Light could represent the archetypes of the mystic/healer and the warrior/prophet for boys who are looking for powerful, life affirming portrayals of men. When contemporary culture is rife with negative images and stereotypes of men, boys may be longing for more positive images of men (Brozo \& Schmelzer, 1997). The entertainment and sports industries provide "deplorable" role models for boys (p.5) and literature could present the possibilities of tapping into positive aspects of ancient archetypes. Some students preferred upbeat, less painful narratives with protagonists who are not in dire straits, and many books by writers of First Nations descent exist that tell the story of exemplary people.

One such book is Barbara Hager's Honour Song, a small book about big people published in 1996. Honour Song is a collection of sixteen interviews that Hager had with influential First Nations people: architects, politicians, educators, singers, and athletes. I used this book in my Humanities (combined English Language Arts and Social Studies) classes. These eight men and eight women discuss their hopes and dreams for themselves and for First Nations people. "Success in aboriginal Canada," Hager learned, means becoming a "source of pride for all aboriginal people, and with that comes the responsibility of returning some of that success" (Hager, 1996, p.ix). The students with 
whom I worked, shared the desire to be a source of pride and to give back to their community.

I left the community in 2001, but if I were still working in Big River today, I would have many new books to offer my students. My senior students could read Porcupines and China Dolls, by Robert Alexie (2002), another writer from the Northwest Territories. The title refers to a recurring image from the protagonist's childhood spent in residential school : the "girls had been scrubbed and powdered to look like china dolls and the boys had been scrubbed and sheared to look like porcupines" (King, 2002. p.116). Much more literature by First Nations people has been written, and includes the young adult fiction I could not find previously.

From 2002-2007, when I no longer worked in a predominantly First Nations community, I still offered literature by people of First Nations authors. Boys in my grade 12 class read Joseph Boyden's Three Day Road in a literature circle. In conversation with the boys, I learned that they appreciated Boyden's portrayal of the friendship between Elijah and Xavier, two young Cree men from northern Ontario more than the graphic images of the brutality of World War One. Personally, I liked the second storyline of Niska, Xavier's aunt, and the way the windigo (a mythic cannibal figure from Anishnabe stories) winds his eerie way through the story. This book was worthy for its many literary merits, but also because it presented the opportunity for my current students to learn about ways that were not their own. "Literature can open the door to other cultures and introduce students to ideas and insights they would otherwise not have encountered" (Landt, 2006 p. 691). 
But multicultural exposure is certainly not the sole purpose of any book, and it would be wrong for any reader to think that one book could be representative of a culture. First Nations culture is comprised of many cultures and each one is vibrant and changing. Writers of First Nations decent contribute to the diversity in literature, and take on subjects and concerns as varied as their backgrounds, experiences, and life styles. And it seems, according to Thomas King, that many First Nations writers "are making a conscious decision not so much to ignore non-Native readers as to write for the very people they write about" (King, 2002.p.115). And this is the connection I hoped my students would make so many years ago. At that time, I was looking for books that would allow my students to see themselves and to recognize their experiences or the experiences of people they knew, in the texts we read at school.

I wanted my students to discover the rich world that waited for them in books. Johnny Gebhardt describes in one of his letters to Joshua in A Quality of Light, how he became a reader. He was sent to camp one summer, and after the counselors realized that he was not going to participate in the activities they left him alone. "They had this little library in the main cabin. Hardy boys, Nancy Drew, Treasure Island, Peter Pan, the usual stuff for kids. But they also had a book called Indians. That's all, just Indians. I opened that book and I was gone" (Wagamese, 1997. p.77). It is a curious paradox that one loses oneself in a text, only to find oneself. I wanted my students to find ideas and images for themselves, to extend and challenge their thinking and feeling, and I also hoped that books might provide some comfort on the journey that was negotiating their identities in school. I hoped that they could take on the identity of "reader" without feeling that they 
had "to sacrifice their ethnic, cultural, or language identities to assimilate into the dominant culture" (Nieto, 2002 as quoted by McCarthy, 2002 p. 129).

And finally, in addition to what I thought one good book might do for an individual student, those books created a common ground for us, a place where my students and I could meet to discuss our responses to the books, our ideas and our lives.

\section{References}

Alexie, R. (2002). Porcupines and china dolls. Toronto, ON: Stoddart Publishing Co. Berger, T.R. (1999). A long and terrible shadow: White values, Native rights in the Americas since 1492. Toronto: Douglas \& McIntyre.

Boyden, J. (2005). Three day road. Toronto: Viking Canada/Penguin

Brozo, W.G., \& Hargis, C.H. (2003). Taking seriously the idea of reform: One high school's efforts to make reading more responsive to all students. Journal of Adolescent and Adult Literacy, 47(1), 14-23.

Brozo, W.G., \& Scmelzer, R.V. (1997). Wildmen, warriors and lovers: reaching boys through archetypal literature. Journal of Adolescent and Adult Literacy, 41(1), 4-11.

Culleton, B. (1984). April Raintree. Winnipeg, MB: Pemmican Publications.

Greenbaum, V. (1997). Censorship and the myth of appropriateness: reflections on teaching reading in high school. English Journal, 86(2). 16-20.

Hager, B. (1996). Honour song. Vancouver, BC: Raincoast Book Distribution Ltd.

Highway, T. (1988). The Rez sisters. Saskatoon, SK: Fifth House Publishers.

Highway, T. (1989). Dry Lips oughtta move to Kapuskasing. Saskatoon, SK: Fifth House 
Publishers.

King, T. (2002). The truth about stories: A Native narrative. Toronto, ON: House of Anansi Press.

Landt, S. M. (2006). Multicultural literature and young adolescents: A kaleidoscope of opportunity. Journal of Adolescent and Adult Literacy, 49(8), 690-697.

Lutz, H. (1991). Contemporary challenges: Conversations with Canadian Native authors. Saskatoon, SK: Fifth House Publishers.

McCarthy, S. J. (2002). Students' identities and literacy learning. Newark: International Reading Association.

Ogbu, J., \& Simons, H. (1998). Voluntary and involuntary minorities: A culturalecological theory of school performance with some implications for education. Anthropology and Education Quarterly, 29, 155-88.

Ogbu, J. (2004). Collective identity and the burden of "acting white" in black history, community, and education. The Urban Review, 36(1), 1-35.

Van Camp, R. (1996). The Lesser Blessed. Vancouver, BC: Douglas \& McIntyre.

Wagamese, R. (1997). A Quality of Light. Toronto, ON: Doubleday Canada Limited.

Wheeler, J. (1989). Brothers in Arms. Winnipeg, MB: Pemmican Publications.

Williams, B.T. (2004). A puzzle to the rest of us: Who is a 'reader' anyway? Journal of Adolescent and Adult Literac,y 47(8). 686-698

Young-Ing, G. (1993). Aboriginal peoples' estrangement: marginalization in the publishing industry. In J. Armstrong (Ed.), Looking at the words of our people:

First Nations analysis of literature. (pp. 177-87). Penticton, BC: Theytus Books Ltd. 